Article

\title{
Religion without Belief and Community in Africa
}

\author{
Hermen Kroesbergen $\mathbb{D}$ \\ Department of Dogmatics and Christian Ethics, University of Pretoria, Pretoria 0028, South Africa; \\ hermen.kroesbergen@gmail.com
}

Received: 13 March 2019; Accepted: 20 April 2019; Published: 25 April 2019

\begin{abstract}
Religion in Africa is in many respects becoming religion without belief and community again, I will argue in this article. Europeans arriving in Africa did not recognize African religion, because Africans did not have the kind of belief and community characteristic of European concepts of religion. Pentecostalization brings back this African concept of religion without worship groups defined by an adherence to a particular picture of the world, and I will show what this means at grassroots level. What matters in this concept of religion is whether something works rather than some implied truth-claims about the world. Instead of forming groups, Neo-Pentecostal ministries are more often organized around the vertical relationship between the man/woman of God and his/her client. The Pentecostalization of Christianity in Africa has led to a form of religion in which beliefs and community are not of central importance.
\end{abstract}

Keywords: African Christianity; concept of religion; belief; community; Neo-Pentecostalism

A remarkable discovery when Europeans began to explore other continents was the absence of religions. From the Americas, to the Pacific islands and Africa, European travellers reported that the local population did not have a religion (Chidester 1996, pp. 11-16). For several reasons this 'discovery' was reevaluated over time: indigenous religions were being recognized, albeit often as worshipers of idols. For Southern Africa, however, such a recognition was long delayed. In the eighteenth century, the French philosopher Diderot describes in his Encyclopédie the religions of Africa: Christians in Egypt and Abyssinia, Muslims in North and East Africa, and local worshipers of idols throughout Africa. In Southern Africa, however, he notes that, "there are people who have no idea of religion" (quoted in Chidester 1996, p. 19). Up until the 19th century, travellers noted that, "indigenous southern Africans had 'no appearance of any religious worship whatever'" (Chidester 1996, p. 19). Scholars have pointed out that there were all kind of ideological reasons for not seeing religion among the people of Africa: it legitimizes bringing Christianity and treating Africans as inferior since if they do not have religion they cannot be considered to be fully human (Chidester 1996). I doubt whether many people would have sat down to devise strategies for how to oppress Africans. It is more likely that most colonizers, missionaries and travellers did not see religion, simply because they did not find those characteristics that they had come to expect of religion.

It is not as strange as it seems that the first Europeans did not find religion in parts of Africa. Many African languages do not even have a word that could be faithfully translated as 'religion' (Clarke 2014, p. 34). Several scholars have pointed out that "the concept of 'a' religion as a particular system of beliefs embodied in a bounded community" was relatively new in Europe itself as well, yet, after Reformation and Enlightenment this is what religion came to mean for people from Europe: a confined community of people who share a particular system of beliefs (Schilbrack 2010, p. 1113).

The difference between this traditional Western concept of religion and an African concept of religion can be illustrated by the difference between critical responses towards them. The initial secular response to Christianity in the West is: "But it is not true: there is not a being named 'God' who created the earth, lives in heaven, and so on, as you claim!" Here truth-claims are disputed. The initial secular response to African Traditional Religions is: "But it does not work like that: illness is not caused by 
the jealousy of someone named a 'witch,' whether a chicken dies of benge does not tell us anything, praying to the ancestors does not bring rain, and so on, as you claim!" Here it is not truth-claims that are disputed, but whether it works.

When early anthropologist E.E. Evans-Pritchard assures us that "Witches, as the Azande conceive them, cannot exist" this is a very different claim from the secular claim that God does not exist (Evans-Pritchard 1937, p. 63). Evans-Pritchard does not deny that people designated as 'witch' exist, nor does he deny that they may be found to have the black witch substance in their bodies for which he gives some possible explanations. Evans-Pritchard denies that the people named witches can do the things they are claimed to do.

Religion in the West, in particular in its Protestant variety, traditionally centers on a picture of the world. New members learn this picture through catechism and commit themselves through a confession of faith which recounts the basic elements of this picture of the world. Other aspects, like trust and hope, are important in religion in the West as well, but most often they are bound up with the picture of the world that is assumed: one has to hope for a particular world to arrive, and trust the God is able to bring this about. African Traditional Religions are not so much about a picture of the world, but about how to get things done and about discovering what ultimately caused something to happen.

In this article, I will argue that Christianity in Africa, despite the Western missionaries' efforts, has become a truly African religion in the sense of the distinction described here. In particular due to the Pentecostalization of Christianity in recent years and the flourishing of Neo-Pentecostal prophets, the kind of religion present in much of African Christianity is the 'what works' kind. The initial secular response to Neo-Pentecostal religion in Africa would be similar to the response to African Traditional Religions: "But it does not work like that: health and wealth is not created by tithing, people do not rise from the dead through prayer, and so on, as you claim!"

Obviously, Pentecostalism and Neo-Pentecostalism come in many forms and guises, and there are local differences within the vast continent of Africa, yet, there are common trends as well. One finds the same practices and developments among Christians all over Sub-Saharan Africa. Between Christians of, in particular, the English-speaking countries of Sub-Saharan Africa, there is much exchange of ideas, practices and prophets. To give some examples, many people in Zambia watch films and TV-stations and read books from Nigeria and Ghana. Developments in Christianity that we observed for Southern African countries, were no different from those experienced by colleagues in Ghana and Kenya. There are many Nigerian pastors in Zambia and South Africa, and Malawian prophet Shepherd Bushiri's church has branches in South Africa and Nigeria. The trends and developments of Christianity in the English-speaking countries of Sub-Saharan Africa share too many similarities to be discussed in isolation. For this article, I will treat them therefore as one movement.

Interaction with the context of African Traditional Religions changed the kind of religion present in Christianity. Many people in Africa do not ask each other "Do you believe in God?" instead they ask "Where do you pray?" This may be not because it is assumed that everyone believes in God, but because beliefs do not matter that much. 'Belief' in the sense of 'taking something to be true' is not that important in such a context, nor is, therefore, a community of people who share the same beliefs. Religion in Africa is in many respects becoming religion without belief and community again.

After introducing the contrast between the two concepts of religion, I will analyze important aspects of contemporary Neo-Pentecostal practice in Africa to show how Christianity in Africa has become more like African Traditional Religions in its concept of religion, bringing out how this concept is lived at grassroots level.

I will begin by looking at the self-help style of sermons and books in Neo-Pentecostal circles. In many Neo-Pentecostal sermons and books Christians are taught which steps to take in order to reach a particular goal. What matters is to find out what works. 'To believe in this or that' may be one of the steps that is presented, but this merely shows how different 'belief' functions in this context in 
which 'to believe in' and 'claiming the existence of' are two very different things. This African concept of religion implies a belief that is not what belief is in a traditional Western concept of religion.

Next, I will consider what has been described as 'church hopping' and as 'spiritual insecurity': a large number of people in Africa move from one prophet to the next, and are often extremely skeptical about prophets they are not frequenting at the moment. Instead of describing this as 'pragmatic' in a secular sense, or as 'insecurity,' I will argue that it reflects a traditional African concept of religion. This concept of religion suggests an insecurity that is not really insecurity at all, at least not insecurity about what to believe.

Finally, I will interpret the popular practices of 'mass prayer' or 'collective-personal prayer,' where people pray loudly, often in tongues, moving around, everyone at the same time, and 'altar calls.' I will argue that these practices show the kind of community, or rather, lack of community, that belongs to this concept of religion. Everyone tries to find a way to deal with his or her own problems. Because of its focus on healing, African Christianity has often been compared to a hospital. In 'mass prayer' and 'altar calls' we can see the kind of community that is present in hospitals as well: people are together in one building, but everyone is there to get his or her problem addressed by the powerful man or woman of God. The kind of community that comes with this African concept of religion, is, actually, in many respects not really a community at all.

Let us start, however, with the contrast between the two concepts of religion in general. These concepts will afterwards be studied in more detail, when we turn to the contemporary Neo-Pentecostal practices that can be found throughout the English-speaking countries of Sub-Saharan Africa.

\section{Whatever Works: Religion That Is Not Religion}

The kinds of religion that existed in Africa before the Europeans arrived were kinds of religion that had, as anthropologists Jan Platvoet and Henk van Rinsum say, a "very low visibility" (Platvoet and van Rinsum 2003, p. 17). Platvoet and Van Rinsum describe pre-colonial African religions as follows, "They were complex religions, consisting of loose conglomerates of inarticulate and variable beliefs about many different categories of unseen beings, properties and qualities" (Platvoet and van Rinsum 2003, p. 17). Religions consisted of loose sets of vague ideas and practices. Pre-colonial African religions were most often pragmatic, both in the sense that they easily accommodated new ideas when the situation required to do so, and that their functions and goals were very down-to-earth. According to Platvoet and Van Rinsum, "These anthropocentric, inarticulate religions were also highly adaptive and adoptive, at once mono-, poly-, and pan-theistic" (Platvoet and van Rinsum 2003, p. 18). The point in these religions did not lie in theoretical speculations about the nature of reality. These religions consisted of a wide and diverse group of practices connected to a variety of vague ideas that were performed whenever people felt that something needed to be done, either to obtain what they desired, or to be protected from what they feared.

Many scholars have noted before that African religions are pragmatic in nature and that their emphasis is on power and protection. Religion in Africa has been described as "power-oriented," or "a survival strategy" (Burgess 2008, p. 31; Asamoah-Gyadu 2010, p. 63). A number of classic interpreters of African ways of thinking, such as Placide Tempels, John Peel and Laurenti Magesa, in fact identify in all African behaviour a quest for power (Clarke 2011, p. 193, n. 58; compare Marshall 2009). The goal of religion in Africa is most often not heaven or mystical contemplation, but it is meant to transform people's lives in the here and now (Hackett 1988, p. 326). Through religion people in Africa are said to look for spiritual help to obtain this-worldly goods; religious rituals are intended to secure flocks, crops, fertility, wives and children (Gifford 2004a, p. 172).

Many scholars note the formal parallels between African Traditional Religions and the prophets of both African Initiated Churches (often founded early in the twentieth century) and contemporary Neo-Pentecostal churches (Walls 1996, p. 190). The African map of the universe remains the same (Kalu 2008, p. 169). Pentecostalization has changed Christianity into a kind of religion that people in Africa think will help them, as religion has always done in Africa (Onyinah 2007, p. 314). For both 
many anthropologists and Neo-Pentecostal theologians themselves this explains the contemporary success of Neo-Pentecostalism in Africa. What is particularly attractive for Africans in Neo-Pentecostal practices, it is said, is their resonance with what Kwame Asamoah-Gyadu calls a "problem-solving approach to religion" (Asamoah-Gyadu 2013, p. 63). African religion has always focused on the practical consequences of religion and the explanation of this-worldly events, and Neo-Pentecostalism continues that trend (compare Asamoah-Gyadu 2013; Burgess 2008; Faulkner 2016; Hackett 1988; Horton 1993; Wariboko 2014). Scholar of religion Paul Gifford explains, "The traditional African religious imagination expects religion to perform the function (in Horton's words) of 'explanation, prediction, and control of space-time events.' The deficiencies of Western mission Christianity, which over the last few hundred years has ceased to perform this function, have led Africans to institute their AICs [African Initiated Churches] and more recently to turn in increasing numbers to charismatic churches, where this function is openly championed" (Gifford 2004a, p. 173).

Religion in Africa used to be, and is again, in many ways not about truth-claims adhered to by a particular group, but about what works. Religion in Africa is not about beliefs and community, but about power and pragmatic ways to use it. Pre-colonial African religions were often demonized and later ignored by Christian missionaries and mainline churches in Africa, but Platvoet and Van Rinsum conclude, "They took sweet revenge, however. The traits marking religious practice in pre-colonial societies continue to deeply determine the pragmatic plural religious allegiance of many Christians and Muslims in modern Africa" (Platvoet and van Rinsum 2003, p. 18; compare Meyer 1999). Religion in Africa seems to be becoming religion without belief and community again.

Before elaborating on the different aspects of this concept of religion in contemporary African Christianity in more detail, let me first try to refute the initial secular response through which I introduced this type of religion in the introduction. The approach taken in that refutation underlies the analysis in the rest of this article. The initial secular response to religion as a system of beliefs is, "But it is not true!"; the initial secular response to the kind of religion we find in both African Traditional Religions and contemporary African Neo-Pentecostalism is, "But it does not work like that!" Does it make sense to assume that people in Africa believe things to work that obviously do not work? Does it make sense to assume that people in Africa believe in some improbable kind of mystical causality? Everyone has weird ideas from time to time-that is part of our shared form of life-and dire circumstances such as those in many parts of Africa may increase their number, but does it make sense to assume that people in Africa have improbable ideas in an entire area of life? Ludwig Wittgenstein said, in response to the early anthropologist James Frazer who portrayed Africans as not understanding how things work, "It will never be plausible to say that mankind does all that out of sheer stupidity" (Wittgenstein 1993, p. 119). I hope to avoid the risk of ending up in retorting accusations of who is taking people seriously or not, or who shows lack of imagination or not-is it lack of imagination to be unable to imagine people to believe rain-rituals to be effective, or is it lack of imagination to be unable to hear "Ancestors, give us rain!" or "God, make us prosper!" in a different way from "Chief, give us a piece of land!"? Instead of asking how can people believe these impossible things, I propose we consider how do they believe (Wittgenstein 1997, p. 87). This may shed a different light on what kind of reality and effectiveness practitioners of African religions believe in. Practitioners of African religious practices appear to believe things about how the world works that are highly improbable, but do they really, if one takes into account that in other parts of their lives they are perfectly well aware of how the world works?

Wittgensteinian philosopher Peter Winch argued against the assumption that there is a straightforward contradiction in African ideas about what works. He uses as an example anthropologist E.E. Evans-Pritchard's description of Azande oracles where the survival or death of a fowl after being administered a ritual poison provides the answer 'yes' or 'no' to a particular question. Winch counters the initial secular response to this practice "But the survival or death of a fowl does not tell us anything about the success or failure of a particular enterprise!" by reminding us that these Azande oracles "are not a matter of intellectual interest but the main way in which Azande decide how they should act. If the oracle reveals that a proposed course 
of action is fraught with mystical dangers from witchcraft or sorcery that course of action will not be carried out; and then the question of refutation or confirmation just does not arise" (Winch 1972, p. 20). The point of oracles is not to form correct beliefs about the world, but the point is guiding an action. Even if the oracle advises in favour of a particular action, a theoretical refutation of oracles within the practice of the Azande does not arise. Winch concludes, "it is the European, obsessed with pressing Zande thought where it would not naturally go - to a contradiction - who is guilty of misunderstanding - not the Zande. The European is in fact committing a category-mistake" (Winch 1972, p. 26). To say "But it does not work that way!" of African religious practices is to treat these practices as a primitive form of science or engineering. In that case the skeptical exclamation would make sense since a contradiction would arise between this form of engineering and the common sense engineering or working practices of which Africans in their daily life show to be aware, such as building a house, working the land or making a business deal. The fact that in day-to-day life African religious practices most often do not naturally lead to such contradictions, shows that interpretations which push it in that direction misunderstand the category to which these practices belong. African religion does not belong to the category of beliefs and truth-claims, but it does not belong to the category of practical engineering either. In the rest of this article I will explore what is the proper category to which the African concept of religion belongs, beginning with the way in which contemporary African religion does not involve beliefs.

\section{Self-Help Sermons: Belief That Is Not Belief}

Many early missionaries in Africa are reported to have had trouble getting across the notion of 'belief;' people did not see the point of believing (Meyer 2007, p. 13). They found that for people in Africa religion was not about belief, but about performing rituals in order to access powers for healing and protection. Anthropologist Malcolm Ruel says of the Kuria people in Kenya, "What Christian conversion has done for Kuria has been, not simply to substitute one set of beliefs for another but to introduce to them the idea of belief itself" (Ruel 1997, p. 11). Belief in the sense of "the attitude of taking something to be true" was often not that important in African life (Blum 2018, p. 642n). Philosopher Wilfred Cantwell Smith notes that unsuspecting Westerners tend to ask of people belonging to a different religion 'What do they believe?' as if this were an obvious question to start with (Smith 1962, p. 180). Nowadays in academic circles it is common to criticize the "ideology of belief, that is, an assumption deriving from the history of Christianity that religion is above all an interior state of assent to certain truths" (Lopez 1998, p. 31). Many scholars or religion see "compelling evidence that belief ought to be avoided altogether as a remainder of a reformed theology" (Lofton 2012, p. 52). Belief does not need to be the core of religion, so we can see in Africa and most non-Western parts of the world. Belief was not that important; and religion was not as unified as Christianity is either: anthropologist Clifford Geertz sees Christianity as a uniform replacement for a crowded arsenal of tools in traditional religions (cf. Landau 1999, p. 29). Contemporary Neo-Pentecostal practice in Africa makes one wonder whether the introduction or imposition of both belief and uniformity was ever very successful. Of course, the Pentecostalization of Christianity in Africa takes many different forms, and in all of these belief does play some role, as does community, yet, in this article I wish to show that belief and community are not as important in the concept of religion that we find in the movement represented by contemporary trends and developments of Christianity in the English-speaking countries of Sub-Saharan Africa, as in the traditional Western concept of religion.

One way in which the relative irrelevance of belief can be seen is in the way the Bible is used in African Christianity. In the African way of reading scripture, the traditional hermeneutical and critical approaches to the Bible as they have been developed in Western Christianity are often completely by-passed: people apply their reading of the Bible directly to their own situation (Walls 1996, p. 198). Hermeneutics in contemporary African Christianity is more "praxis-oriented;" what matters is how this text can transform someone's life (Kalu 2003, p. 99). Important in the African way of dealing with the Bible is what Paul Gifford calls "the performative or declarative use of the Bible" (Gifford 2008, p. 206). The words become effective through the act of an anointed preacher speaking them. Intellectual discussion about an interpretation of the text is beside the point, since if one questions the preacher's 
interpretation, one risks the practical benefits that he or she has been promising (Burgess 2008). It is mainly those practical benefits that make reading scripture important. We could say that the Bible in African Christianity is treated as a self-help text, and indeed most sermons and books on the Bible that one finds in the English-speaking countries of Sub-Saharan Africa are written in a style that is very similar to the genre of self-help literature familiar in the West.

Living in Zambia for six years, training future pastors, I noticed that people did not differentiate much between pastors and motivational speakers. Motivational speakers are invited to lead overnight prayer meetings and pastors are hired to address the employees of secular companies. Elsewhere as well, many Pentecostal preachers double as purely secular business consultants, and many authors of African self-help books and pamphlets are also leading their own Pentecostal ministries (Gifford 2004b, p. 55; Newell 2008, p. 20). In sermons one often finds "Biblical verses mixed with popular self-help discourses [to] exhort converts to identify the sources of their frustration and suffering and embark upon a process of continual self-overcoming" (Corten and Marshall-Fratini 2001, p. 7). Whereas self-help pamphlets and books often "serve as commentaries or companions to the Bible" (Pype 2015, p. 366).

Kwame Asamoah-Gyadu observes that African charismatic pastors publish extensively. There is a substantial local market of popular Christian books in Africa (Asamoah-Gyadu 2013, p. 62). These books differ from many Western theological books. They are not "academic material in the real sense of the term" as Asamoah-Gyadu notes, but they are practical guides written for a broad audience (Asamoah-Gyadu 2013, p. 62). Sermons and Christian books alike in Africa are "written much like secular, popular psychology self-help books," anthropologist Maria Frahm-Arp observes (Frahm-Arp 2014, p. 157). Like the television programmes of the throughout the continent popular televangelists, they "serve as a counselling discourse; a means for individual transformation; as motivational, self-help, teaching resources that change lifestyles; and a source for achieving progress and social uplift," Ogbu Kalu adds (Kalu 2008, p. 109). Often these sermons and books "sound like business management strategies and motivational recipes designed to inspire people and restore hope" (Kalu 2008, p. 256).The listener or reader is not so much told what to believe, but he or she is told which steps to follow and which principles to apply in order to achieve one's goals, that is, the practical benefits that religion in Africa is supposed to deliver.

Let me give some examples from the most widely available authors in Christian book stores in Lusaka in 2015-in the bookshops I checked they all had an entire bookcase dedicated to themselves. David Oyedepo from Winners' Chapel International from Nigeria concludes his Covenant Wealth with the chapter 'Conditions for Prosperity' in which he mentions "the conditions by which the principles presented [to obtain covenant wealth] will function" (Oyedepo [1992] 2011, p. 83). His Understanding Financial Prosperity explains the '7 Pillars Of Kingdom Prosperity' and concludes with urging readers to 'Make A Choice for Change' (Oyedepo 2005). American pastor Kevin Copeland writes about The Laws of Prosperity, whereas his wife Gloria Copeland sets out A Roadmap to Spiritual, Emotional, E Financial Wholeness as is the subtitle of her book God's Will is Prosperity (Copeland 1974 and Copeland 1978). Derek Prince's The Promise of Provision explains the 'Five Principles of Provision,' 'Three Practical Steps to Take,' and 'Five Conditions for God's Abundance' (Prince 2011). On the cover of God's Plan for Your Money Prince promises us that "The right attitude to money reveals your attitude to God and produces the right results," presenting "time-tested spiritual principles" in order to "Break the spirit of poverty in your life; Rise up from debt to financial freedom; Enjoy a life of success and prosperity; Prosper during hard economic times," and encourages us to: "Start today to walk in God's supernatural provision-and change the course of your life" (Prince 1986). Christian books in Africa like these are full of steps, principles and laws to follow in order to achieve success and prosperity.

In these books and the sermons that often follow a similar pattern, parts of the Bible that contain something like self-help advice are often used. I myself, for example, have heard many sermons on the book of Proverbs. Traditional African philosophy has often been described as consisting of proverbs, so there is an obvious continuity in this respect. Scholar of African Christianity Andrew Walls mentions the relative importance of the book of Leviticus in Africa. I have not noticed that myself, but Leviticus' 
structure of providing clear rules for how to please God in order to obtain his blessings resembles many sermons I have heard and African books I have seen.

Elsewhere, I have discussed in detail the Neo-Pentecostal interpretation of Matthew 6:33, "Seek first his kingdom and his righteousness, and all these things will be given to you as well" (see Kroesbergen 2017). This Bible verse is one of the most used Bible verses by both propagators of the Neo-Pentecostal Prosperity Gospel and their opponents. Neo-Pentecostal literature takes this verse to describe a technique for obtaining prosperity. I discuss how difficult it is to tell how Christians use texts like these in their lives (Kroesbergen 2017, pp. 126-30). Careful, specific analysis is needed, which falls beyond the scope of this article. Here, I will use another common form of using the Bible in contemporary African Christianity to highlight the common structure of much African Neo-Pentecostal literature, namely to investigate the narrative of one of the heroes of the faith (Gifford 2004b, p. 72). These are people from the Bible whose lives can serve as role models to obtain the success and prosperity that they received. As Paul Gifford observes for Ghanaian new Christianity, "The Bible functions primarily as a repository of narratives, overwhelmingly of the miraculous, about, (in what appears to be their order of importance) Abraham, Joseph, Elijah and/or Elisha, David, Daniel, Joshua, Moses and Job" (Gifford 2004b, p. 72). Pastors investigate who is blessed by God and try to determine what he (or sometimes she) did to earn those blessings. The story is used to find the tricks that work. What should someone do to make God bless him or her? We can see how this works in the description by the Ghanaian Pentecostal pastor Kwame Asamoah-Gyadu of how the story of Jacob is used in many Neo-Pentecostal publications.

Jacob is an interesting figure in the Bible. He has a close relationship with God, yet he often gets what he wants through lies and betrayal. Most sermons I have heard about him in the Netherlands were quite ambiguous: on the one hand, Jacob is clearly the good guy in the story; on the other hand, it is wrong how he cheats his brother Esau and his uncle Laban. In African Neo-Pentecostal sermons and books this ambiguous reading is condemned: "Jacob was not an ambitious cheat; he simply had a strong sense of his bargaining power" (Asamoah-Gyadu 2013, p. 165). Asamoah-Gyadu quotes a book by a Neo-Pentecostal pastor who holds that "the life of Jacob 'portrays vividly a quest for supremacy' because 'he outsmarted Esau and out-paced Laban to grab prosperity and wealth"' (Asamoah-Gyadu 2013, p. 165). Jacob is presented as a role model: "The choices Jacob made, no matter how morally wrong, are interpreted as 'smart moves' or 'skillful negotiations' needed to succeed in today's turbulent, capitalist, consumerist, and competitive world" (Asamoah-Gyadu 2013, p. 164). Elsewhere, Asamoah-Gyadu concludes that "Jacob is [ ... ] reinvented in contemporary Pentecostal preaching, not as a cheat but as one in whose life God's purposes were fulfilled through taking advantage of situations in which he found himself" and "The contemporary charismatic interpretation is that life is about smart negotiations" (Asamoah-Gyadu 2016, pp. 164-65). The life of Jacob teaches us how to get what we want by any means necessary.

Asamoah-Gyadu himself admires this reinterpretation; according to him it "underscores the innovative attempts of contemporary Pentecostal preachers to preach a gospel that in their eyes addresses contemporary challenges and speaks directly to the concerns of modern African audiences" (Asamoah-Gyadu 2013, p. 166). As Paul Gifford says, in African Neo-Pentecostal preaching the Bible "functions as a repertoire of life-changing experiences" (Gifford 2004b, p. 73). Investigating the life narrative of someone in the Bible who was blessed by God, pastors find a list of steps, conditions and principles that people can apply in their own lives to ensure that God will prosper them like he prospered those role models from the Bible. The sermons and books in this context are not about what someone should believe or what the world is like, but about which steps are effective, about what works.

Now, to believe or to have faith can be one of the steps necessary to reach the goal, but in that case the context of following steps in order to obtain a reward changes what belief is. Faith in the context of African Neo-Pentecostalism is often not about someone's inner state, but about improving one's situation in the world. Faith, when it is recommended in one of these self-help style books or 
sermons, is not an inner attitude, but a device, a tool to be used (Meyer 2007, p. 15). As Ogbu Kalu describes, "The theology points to faith as the route to prosperity. True faith is defined beyond mere belief: it is acting on the word, speaking into reality what does not exist, and dreaming and envisioning the desired goals" (Kalu 2008, p. 255). Kalu is referring here to the practice of 'positive confession': positive confession is to speak out what you hope that will happen as if it were already certain that you get it. Doing so would compel God to actually give to you the thing you confessed you already have. This practice originated in the American New Thought movement within which the mind was central. Positive confession within New Thought was meant to change your mind, which would in turn change the world. As I have argued elsewhere, in the African context the speaking or declaring is the most important part of positive confession (Kroesbergen forthcoming). Believing here is about speaking particular words, and not about considering something to be true.

Psychologist Bregje de Kok discovered during conversations with Malawian Christians that they "can use 'believing in' $x$ in a way which makes it not identical to claiming the existence of $x$. More specifically, 'not believing in' does not mean not acknowledging existence" (de Kok 2004, p. 46). People will tell you that of course they do not believe in witchcraft, but they do take all kind of counter-measures against witchcraft at the same time. De Kok observes that, "Malawian Christians use 'believe in' in their talk in such a way that as long as one shows not to direct one's behaviour at ancestral spirits or witches, or at least not out of free will, one does not 'believe in' the ATR [African Traditional Religions]-reality" (de Kok 2004, p. 47). This 'believing in' as consciously directing one's behaviour in a particular direction is the kind of 'believing in' that can form one of the steps recommended during a Neo-Pentecostal sermon as well. As anthropologist Adam Ashforth notes for his South African informant, "'belief' is not simply the passive acceptance or rejection of a cognitive 'idea' but a form of action in itself" (Ashforth 2000, p. 246). To 'believe in' in the sense of taking something to be true is not what matters, to 'believe in' is an action and is merely one of the steps that might work to obtain what one wants concerning jobs, marriage, children, visas, houses, demons or witchcraft. In this context 'to believe in' and 'claiming the existence of' are two very different things.

Malcolm Ruel describes how he as a young anthropologist went to the Kuria people in Kenya to investigate the role of religious beliefs in the lives of these people (Ruel 1997, p. 4). Over time, however, he discovered that these people did not hold many beliefs about the supernatural at all. They were simply doing their rituals: "Ritual was above all the means by which these life processes [the growth of people in society, of crops and domestic animals upon which people depend] were ordered and made secure" (Ruel 1997, p. 8). Kuria people speak of a spirit world but in a much more down-to-earth way than he had expected. A spirit for them is not "the hypothesized supernatural counterpart of the individual person," or something like that, but to speak of a spirit is simply their way to order plain empirical facts (Ruel 1997, p. 7). Ruel concludes that, "Their religion, it seemed to me, was a matter more of 'knowing' than of 'believing'" (Ruel 1997, p. 5). Yet Ruel calls it "knowing" not because he holds that the Kuria's beliefs are justified and true, but because it is not a matter of belief at all. Belief in the context of African religion is often not belief.

Scholars of religion Stephen Ellis and Gerrie Ter Haar correctly point out that most people in Africa do not intend their stories about the spirit world to be metaphors for the economy or something like that as other scholars of religion assume, but that people intend what they say to be taken literally (Ellis and Haar 1998, p. 179). Yet the fact that it is to be taken literally is not the point. They may not mean to be not taken literally, but that does not necessarily imply that they are engaged in a project to portray the world as it really is either.

Paul Gifford emphasizes that the "absence of historical or 'critical' perspective does not make these churches 'fundamentalist' (a term best avoided, because of its special link with particularities in the North American scene), but it gives their use of the Bible a particular character, one very different form that characteristic of mainline churches of the West" (Gifford 2004b, p. 79). Discussions about whether the stories from the Bible are true or to what extent they are true, are discussions that inform the use of the Bible in the West, but, generally, these discussions do not arise in the African context. Therefore 
Gifford considers it misleading to call this new Pentecostalized Christianity in Africa 'fundamentalist': "Of course the participants in this Pentecostal explosion would presume the Bible is inerrant, but in what it promises for me, not in what it claims about history or science. This performative approach to the Bible is not anti-critical or even pre-critical—-the historical approach to the Bible simply does not arise" (Gifford 2008, p. 214). The discussions in the USA within which 'fundamentalism' means something do most often not exist in that way in Africa. In general, people in Africa do not ask whether what the Bible says really happened: it is in the Word of God, so of course it happened, but that is not the point. What matters in most cases in African Christianity is that it is true in the sense of telling us what to do, in providing the steps and principles people can use to obtain what they want from religion. When sermons or books speak of the story of Jacob's life, for example, there is not much question of whether or not everything truly happened as it is described. It seems to be assumed that it did, but that is not what seems to matter. What seems to matter is to find someone who can show you what are the right steps to get what you want, to show what works.

Bregje de Kok investigated how Christians in Malawi consider African Traditional Religions (de Kok 2004). It turned out that they do not see a clash between Christianity and African Traditional Religions (ATR): they do not feel that they have to choose between having their child baptized and performing traditional birth ritual, for example, and see no point in trying to combine the two as is attempted in inculturation theology either. De Kok concludes, "From a western perspective one may be inclined to equate or compare ATR and Christianity as two things of the same kind-namely religion-such an assumption does not do justice to the way Malawian Christians orient to Christianity and ATR" (de Kok 2004, p. 55) African Traditional Religions are not considered to be truly religion. Another interpretation is possible as well: Malawian Christians consider African Traditional Religions and Christianity both as religion, but religion of a kind where you do not have to choose. De Kok notes about Malawian Christians that, "Frequently they appear not to perceive ATR and Christianity as oppositional categories between which they should choose" (de Kok 2004, p. 55). If religion is about what works there is no need to choose: if you are ill and look for a cure, you do not have to choose between a medical doctor, acupuncture and Feng Shui either. As scholar of African religion Paul Landau observes, "Christians continue to engage in practices labelled non-Christian and religious by missionaries, without necessarily seeing them as representing a competing discourse" (Landau 1999, p. 11). According to the African concept of religion as described here, religion is not defined as a discourse, but as a set of tools or steps to follow to receive blessings. In as far as belief does play a role in this concept of religion, it is not as taking something to be true.

The fact that belief in African religion is in many ways not belief changes the interpretation of phenomena like church hopping and double membership as well, and it shows important characteristics of the category to which this kind of African concept of religion belongs, as we shall see in the next section.

\section{Church Hopping: Insecurity That Is Not Insecurity}

There is an almost endless number of churches and ministries in Africa. Every day many new churches and ministries are founded. Starting your own church is not always considered to be strange or sad, as it might be in Europe or the USA, but to have more churches and ministries is often simply seen as more chances to appeal to more people (Kroesbergen forthcoming). Splits and schisms are not always seen as something the church should be ashamed of, but it is often interpreted as a form of evangelism. There are many very small churches and ministries, but the many splits and new churches do not necessarily make churches smaller. People in Africa often frequent more than one church or ministry simultaneously. In traditional mainline churches this sometimes leads to complaints by the leadership about what is called the 'double membership' of their congregants: people still belong to the mainline church and they may still participate in the Sunday morning worship service, but on Sunday afternoon they go to a local Neo-Pentecostal prophet, on Wednesday evening they pay a visit to the new ministry their neighbour founded last week, and on Saturday they have a look at the crusade that an international charismatic star organized in the football stadium. People do often not belong to 
one group, but frequent many different pastors at the same time. The mainline churches complain, because this means that the offerings of their congregants will be divided as well at best; in fact they will probably go to the prophet who promises the biggest returns, which generally is not the minister of the mainline church.

In addition to the phenomenon of 'double membership' one finds the practice of 'church hopping.' People try out a particular prophet and his ministry and if his spiritual powers do not prove to be satisfactory they hop to the next ministry. Of course, not everyone participates in this practice, but its importance can be seen in the fact that this practice is acknowledged in the way people are addressed in newer churches and ministries. In mainline churches congregants are traditionally addressed as belonging to the family; in Neo-Pentecostal ministries visitors are addressed as spiritual seekers and are invited to see whether this prophet works for them. For a while, people may be very committed to a particular ministry, yet this commitment is often not commitment to a group or church, but commitment within a patron-client relationship to their pastor (McCauley 2012, p. 13). Not everyone, but many Christians in Africa are shopping around from one prophet or pastor to the next (van de Kamp 2010, p. 164; Marshall 2009). In contemporary Africa, people change churches like clothes, a Zambian Pentecostal notes (see Cheyeka 2015, p. 239). How could we make sense of this phenomenon?

In Madumo; A Man Bewitched anthropologist Adam Ashforth describes the church hopping of his informant in Soweto whom he names Madumo (Ashforth 2000). Actually it is not really church hopping since Madumo frequents at least as many traditional healers as he visits churches and pastors. After their mother died, Madumo's brothers and sisters threw him out of their family home. A Christian Zionist pastor had prophesied that someone close had bewitched the mother, and his siblings assumed that this must be Madumo. Without a job and without a house, Madumo finds himself in big trouble. Together with Ashforth he sets out to find a solution for his problems by visiting many healers and prophets. Having described these visits, Ashforth concludes, "In my experience, all healers, Christian and otherwise, whatever else they may do, claim to be able to read the past and divine the future of their patients in order to provide a much needed spiritual security in the present for people living in a world littered with evil supernatural forces they ignore at their own peril" (Ashforth 2000, p. 56). Traditional healers and Christian prophets alike claim to offer a solution to Madumo's problems: they can see where in the spirit world these problems originated and which steps need to be taken to put things right.

In an article related to the same situation, Ashforth observes, "Recent decades in Africa, as elsewhere, have seen a proliferation of interpretive authorities, people claiming to know the truth about invisible forces and the ability to manage relations with them, particularly healers and religious entrepreneurs offering access to miraculous substances or holy words and images capable of delivering miraculous healing" (Ashforth 2011, p. 142). In African Traditional Religions people who faced or feared problems would visit this diviner or that traditional healer, and often simply go to the next one if they were not satisfied. In the contemporary situation not much seems to have changed; it is just that Christian prophets and Western doctors have been added to the spiritual authorities one can turn to. Ashforth proposes to speak of a situation of 'spiritual insecurity' in which people do not know which spiritual authority they should trust. In another article on the topic Ashforth concludes, "A place where superfluity of dangers, doubts, and fear engender a pressing need for meaning. The various agencies of authority, such as those embodied in Western institutions, religious organizations, and indigenous healers are unable to impose a generalized hegemony of interpretation" (Ashforth 1998, p. 65). Western doctors, Christian prophets and traditional healers each propose their own set of steps that someone should follow in order to resolve one's difficulties. Given the fact that there are so many possibilities, people like Madumo do not know what to do any more and they drown in spiritual insecurity, hopping from this church to that healer to that doctor and back.

The concept of spiritual insecurity may provide an obvious framework to understand phenomena like double membership and church hopping, but it can easily be misleading as well. Ashforth proposes to focus on 'spiritual insecurity' as an alternative for the traditional focus on belief. Like the scholars 
mentioned above he considers 'belief' to be too much a product of the Western Reformation and Enlightenment. In his descriptions of spiritual insecurity, however, he himself seems still to be trapped in these Western ways of thinking. He states that, "Spiritual insecurity [ ... ] cannot arise in the absence of faith; it flourishes in the space between faith and doubt, for without faith there would be no relationship about which one might worry" (Ashforth 2011, p. 143). Ashforth wished to exchange a focus on beliefs for a focus on (in)security concerning one's relationships with the spirit world, but he constructs these relationships upon prior beliefs.

Ashforth speaks of "interpretive authorities" and "people who claim to know the truth," but I would like to challenge the idea that interpretation and truth are what people who hop from church to healer and back are looking for. Ashforth states about Soweto that, "No one here lives in a single consistent system of interpreting signs emanating from unseen powers, and for every scheme of interpretation there is another, equally plausible and diametrically opposed, way of making sense of the world" (Ashforth 1998, p. 59). It is true that few people in Soweto and Sub-Saharan Africa in general live in a single consistent system of interpretation, but is this consistent system of interpretation what people are looking for? Elsewhere Ashforth notes that, "As a healer, Mr. Mwasapila does not need to articulate a theory of healing other than referring to the power of God. Evidently that is sufficient for a very great number of people" (Ashforth 2011, p. 134). People do not visit this healer to hear his interpretation; they may not even care very much whether he knows the truth about anything. What they want him to do is to prescribe the correct steps to alleviate their suffering: as a healer, one does not need to articulate a theory.

I quoted above that in contemporary Africa people change churches like clothes, but, if we follow this analogy, is changing clothes a sign of insecurity? It can be, but it does not have to be. If someone goes to a doctor, an acupuncturist and a Feng Shui practitioner, most often they do not thereby express insecurity about or interest in the worldviews of these specialists. They simply look for what works. According to Ashforth, "the experience of misfortune in contemporary Soweto undoubtedly presents the famous question 'Why me?' in an urgent and pressing fashion" (Ashforth 1998, p. 63). Yet "Why me?" is more often an exclamation or a response to a bad situation, than that it is a proper question or request for interpretation or truth. If it reflects insecurity, it is not an insecurity about explanations or interpretations, but an insecurity about how to deal with a particular situation. Someone may hop from one approach to the next, but, in general, this has little to do with searching the correct interpretive authority, longing for a single consistent system, investigating claims to know the truth, or spiritual insecurity as such.

Roman Catholic missionary in Zambia Bernhard Udelhoven describes the task of the traditional healer as follows, "The task of the healer and diviner, the $n g^{\prime} a n g a$, is to bring clarity into the diverse spiritual influences on the lives of individual people" (Udelhoven 2017, p. 124). The traditional healer has to bring clarity in people's lives; not theoretical clarity, but clarity concerning how to live with what is happening. Udelhoven continues, "The priest, pastor or the helper in a way has the same task as a ng'anga (diviner): helping an afflicted person to discern spiritual influences by placing them into a wider context and larger horizon, and provoking a response that corresponds with his/her faith and direction in life" (Udelhoven 2017, p. 124). If there is insecurity that religious specialists in Africa are dealing with, it is not insecurity about explanations or the facts of the matter, it is insecurity about how to deal with the situation that has befallen someone. Madumo wishes to know which steps he should take, which plan of action he should follow. When he goes from traditional healer to Christian prophet and back, this is not a whole sequence of conversions from one interpretative scheme or consistent system to the next, he is simply looking for what works for him; whatever belief systems scholars may claim to detect behind the steps these different religious specialists propose. Likewise, someone who in the morning goes to a classical Reformed worship service and in the afternoon to a Neo-Pentecostal prophet, does not show insecurity about the doctrine of grace, for example, or a conversion in that respect, but it merely shows people trying to find what works for them.

In a different way, however, church hopping and the African concept of religion that is being described here, do have to do with insecurity: people are not so much insecure in frequenting different 
prophets and healers, but in frequenting these prophets and healers they are looking for a way to deal with insecurities in their lives. Ashforth referred to the exclamation "Why me?"- this is a question that may look like a request for an explanation, but, in fact, it is a way to respond to an aspect of life that cannot be explained. Philosopher Rush Rhees gives the example of asking "Why me?" after an earthquake took someone's house and child, "There may be a scientific explanation of what has happened; but then 'explaining what has happened' is ambiguous. Suppose there has been an earthquake, and geologists now give an explanation of it. This will not be an answer to the woman who has lost her home and her child and asks 'Why?' It does not make it easier to understand 'what has befallen us.' And the woman's question, though it may drive her mad, does not seek an answer. 'It was fate' may come some day to take the place of asking" (Rhees 1969, p. 16). "Why?" in these cases is not so much a question but a possible response to the devastation of this earthquake; "It was fate" is a possible response as well, and traditional healers and Christian prophets in the context of African religion provide even more possible responses. These responses are not so much ways to solve problems, but ways to deal with them. These responses occupy the place of solutions, but they are a response to what is not solvable. These responses may look like explanations, but they are more often responses to what is not explainable. These responses may seem to provide security, but, in many cases, they are a response to what remains ultimately insecure.

Philosopher Slavoj Zizek reflects upon Plato's dialogue Statesman where the interlocutors discuss dividing the genus 'human beings' into two species: Greeks and Barbarians (Zizek 2014, p. 34). It is concluded that the latter category is not a proper species of human beings: barbarians do not share any characteristics amongst themselves, except 'not being Greek.' It is a "negative pseudo-species," a container for all those who do not fit the proper categories, and Zizek suggests that every division of genera into species may require such a left-over container (Zizek 2014, p. 34). Elsewhere I argued that luck and witchcraft are like such left-over containers with respect to explanations: what cannot be explained we call 'luck' or 'bad luck' or 'witchcraft' (Kroesbergen forthcoming). In this interpretation, to speak of such things is to possess clarity or certainty, but it is to deal with what is not clear and certain. It is a response to the insecurity of the world. It is a normal part of life, but the part that remains insecure.

Imagine having a job interview that goes terribly wrong, and someone tells you "Better luck next time," while someone else says "It had to be this way," and a third person proposes "Maybe it is a sign." These are three different ways to handle this situation. Someone might be unclear about which way to follow, but none of these responses is a theoretical explanation of what happened. After such an experience people generally are not looking for an explanation or interpretation, but for how to deal with the experience.

Anthropologist Nils Bubandt suggests that witchcraft among the Indonesian Buli people is not a tool to explain the world and give meaning to it, as many of his colleagues assume. These colleagues are trapped in the "explanatory paradigm" (Bubandt 2014, p. 238). Witchcraft, according to Bubandt, is by definition something that cannot be "placed within a meaningful order" (Bubandt 2014, p. 6). It is something before which "understanding and the will to know fail," not because it is so complex or hidden, but because that is why we call it witchcraft in the first place (Bubandt 2014, p. 6). Bubandt emphasizes the Buli people's use of an empty Nautilus shell as a symbol for witchcraft: like this shell is always empty when it is found whether on the beach or in the sea, witchcraft is empty, it is the left-over container for what cannot be explained (Bubandt 2014, p. 1). Witchcraft is a negative pseudo-species of the genus 'explanations.' It answers or replaces the question "Why?" not by presenting a consistent system, but by offering a way to deal with what cannot be explained in such a system, by definition. "It was witchcraft" is like saying "Better luck next time," "It had to be this way," or "Maybe it is a sign" after a failed job interview.

In response to Bubandt some anthropologists suggest that witcheraft and other references to the spirit world in Africa function differently (Geschiere 2016; Sanders 2016). In Africa references to witchcraft and the spirit world are said to be not deep philosophical reflections upon that which 
cannot be explained by definition, but a part of everyday life. Yet, I would argue that this does not imply that within this ordinary everyday life talk about the spirit world is not a way to refer to what is unexplainable. References to the spirit world may be common and normal-so much so that that 'knowing' in this respect sounds better than 'believing' as we saw above-but most often the spirit world is also treated as different. Anthropologist Jean Pouillon, for example, describes that Hadjeraï from Chad, "do not believe in [spirits]: this existence is simply a fact of experience: there is no more need to believe in the [spirits] than to believe that if you throw a stone it will fall" (Pouillon 2016, p. 490). Yet, Pouillon also notes that these spirits "act unpredictably, and are the cause of whatever disturbs the natural course of things:" these spirits are normal not because they are explainable or predictable, but because the unpredictable is a normal part of our lives (Pouillon 2016, p. 490). In our day-to-day lives we may look for explanations for all kinds of things, but there always remains things that are unexplainable. We will always need a 'negative pseudo-species' within the genus of explanations: either we exclaim 'Why me?' or we say 'Bad luck!' or we speak of witchcraft and spirits.

In the context of pre-colonial Africa, most people frequented different traditional doctors or diviners who would tell them which steps to take and which potions or charms to use when confronted with particular problems or fears. In the contemporary context of Neo-Pentecostalism many people try out different pastors and prophets with the same goal in mind. For the Azande, Evans-Pritchard tells us, "I was surprised to find a considerable body of sceptical opinion in many departments of Zande culture, and especially in regard to their witch-doctors. [ ... ] Many people say that the great majority of witch-doctors are liars whose sole concern is to acquire wealth" (Evans-Pritchard 1937, p. 183). Yet this scepticism does in no way diminish the fact that people assume that witchcraft exists and charms work. The same double attitude often exists today with respect to pastors, prophets and diviners as well: most of them are considered to be fakes or frauds, but that does not mean that one's own prophet or pastor is not the real thing (Thornton 2017, pp. 186-87). As anthropologist Adam Ashforth notes about Soweto in South Africa, "After some years I learnt that in this priest-ridden place nearly everyone despises the other person's counsellor [ ... ] People here tend to combine a deep faith in the general possibility of the divinatory enterprise with a hearty scepticism about particular diviners" (Ashforth 2000, pp. 89, 106). As he observes elsewhere, "one man's Spirit-filled miracle working pastor is another's devil worshipping Satanist" (Ashforth 2011, p. 143). Saying either 'better luck next time,' or 'it had to be this way,' or 'maybe it is a sign,' or 'it was witchcraft' after a failed job interview is to respond in a particular way to what has befallen you. Not wanting to respond in one of the other possible ways, does not imply that you do not want to respond at all; you may just want to continue looking for what works for you.

Given the common practice of church hopping, religion in the African context is often treated as providing responses to what is not explainable and not knowable and not secure. Within an African concept of religion that belongs to this category, rather than to the category of beliefs about the world, it is no wonder that people in Africa often do not push their religious statements towards their logical consequences or possible contradictions. As Evans-Pritchard noted for the Azande, "Azande do not perceive the contradiction as we perceive it because they have no theoretical interest in the subject and those situations in which they express their belief in witchcraft do not force the problem upon them" (Evans-Pritchard 1937, p. 25). Religion in the African context generally does not concern itself with theoretical matters. Church hopping, therefore, does not need to be the expression of theoretical insecurity. It does not have to be a matter of spiritual insecurity, but it could be a matter of a spiritual response to life's insecurity. In as far as religion in Africa belongs to this category, it would be a category mistake, as Winch says, to interpret church hopping and African religion in general through categories like interpretive authority, single consistent systems, claims to know the truth, or spiritual insecurity.

\section{Mass Prayer: Community That Is Not Community}

According to the traditional Western conception, religion presents a particular system of beliefs, a picture of the world; and those people belong to a religion who adhere to that particular picture 
of the world. Beliefs define who belongs to a particular religious community and who does not. New members become a part of their religion by learning its system of beliefs in the form of a catechism, and they show their commitment to their new community by a public confession of faith which recounts the basic elements of this picture of the world. As we have seen, the African concept of religion could be characterized more faithfully as religion without beliefs; beliefs are often not that important and can be swapped overnight, religion generally does not so much explain the world or tell people which picture of the world to adhere to. Many people in Africa ask each other "Where do you pray?" instead of "Do you believe in God?" because beliefs do not seem to matter that much. Without the emphasis on beliefs, however, religion becomes merely a practice of praying here or praying there; it does not consist of a community of people who share the same beliefs, at least, such a community is not that important anymore. Without the emphasis on beliefs, religion in Africa, naturally, is becoming more like a religion without community as well. What a religion without community is like can be seen in some of the characteristic elements of contemporary Neo-Pentecostal liturgy that are common throughout the Christian parts of Sub-Saharan Africa, such as mass prayer and altar calls.

Mass prayer, or "collective-personal prayer," as it is called by anthropologist Naomi Haynes, is common among Pentecostals around the globe (Haynes 2017a, pp. 37, 47). It is a form of prayer where everyone present prays out loud simultaneously. In Africa "aggressive and extensive modes of prayer" have often been what identifies an Africanized form of Christianity; this is said, for example, of the Aladura ('people of prayer') in Nigeria, which is a group of African Initiated Churches from early twentieth century (Asamoah-Gyadu 2012, p. 165). Nowadays, mass prayer, where many people pray in tongues, has become a defining trait of the Pentecostalization of Christianity (Asamoah-Gyadu 2013, pp. 21, 41). Naomi Haynes notes for Pentecostal services on the Zambian Copperbelt that "more time is devoted to this type of prayer than to any other activity" (Haynes 2017a, p. 37). In 2001 the practice of mass prayer led to a schism in one of the major mainline churches in Zambia, the Reformed Church in Zambia, when about one third of the church was expelled. Practical theologian Lukas Soko researched this schism and describes, "The source of the conflict was the charismatic tendencies that impacted on the traditions and practices of worship in the Reformed Church in Zambia. From nearly all responses [to Lukas Soko's interviews and questionnaires], mass praying ranked top of the list. During mass praying, the other elements caused conflict to take place: speaking in tongues and crying, clapping of hands while praying, rolling on the floor, whistling, worshipping choruses described as noise making, and a disorderly worship style in contradiction to the traditional liturgy" (Soko 2010, p. 170). Pastors who insisted upon mass prayer were expelled. This did not solve the problem however: merely eight years later the RCZ included mass prayer in one of its three prescribed liturgies. Mass prayer is one of the most important elements of worship for contemporary African Christians across the spectrum.

Mass prayer is done together-en masse as it says-but everyone is engaged with their own problems and their own relationship with God. Mass prayer is often seen as exemplifying the Protestant idea that what is of central importance is the individual in his or her communication with God (Haynes 2017a, p. 36). Every individual Christian brings his or her own concerns before God. Mass prayer illustrates that these churches and ministries in Africa are "not really communities" as Gifford states (Gifford 2004a, p. 175). The kind of communities that are not really there, or at least less prominent in Neo-Pentecostal Christianity in Africa are the type of religious communities that were introduced by mostly Protestant missionaries, namely: congregations. Ideally a congregation is a nuclear family-type of gathering where believers meet fellow-believers on the basis of a priesthood of all believers. The community as a group is taken to be the Body of Christ and the pastor merely facilitates communal worship. As I argued elsewhere, the main purpose of religious meetings in Neo-Pentecostal ministries in Africa diverts from this ideal type: it is not so much about shared worship but more about obtaining a particular religious service (see Kroesbergen forthcoming).

Within this context every individual is concerned with finding a solution for their own difficulties. The goal of frequenting a particular church or ministry is often especially to increase the "wealth and well-being of the individual instead of the collective" (Gordon 2012, p. 306). People are often not 
looking for a community in the sense of a group or congregation, but for whatever can help them and addresses their practical needs (Onyinah 2007, p. 314; Cheyeka 2015, p. 241). This quest takes place within the wider context of the community of all human beings, the open-ended, organic type of community is lived in society at large in Africa, as I have argued (see Kroesbergen forthcoming). It has been noted that, in the way that people used to go to shrines for issues related to marriage, employment, or witchcraft, they now go to prayer camps or Pentecostal prophets (Gifford 2004b, pp. 86-87). Within this context 'community' is not something to be sought after or strived for, but something that is always already assumed: people who find themselves in each other's proximity have to find a way to deal with one another. According to this concept of community which is common in Africa, 'community' is not a group that one can decide to join or not, but it is always already given as the basic form of reality on which everything else is founded (see Kroesbergen forthcoming). The question for people is most often not so much what to believe or to which community they would belong, but simply where to take their problems. In his study of the South African Ngoma healing tradition Robert Thornton describes how the Southern African sangoma practices were not part of a religion with beliefs and community, "Southern African ritual systems were not organised in that way. Specifically, they lack a congregation as a 'moral community'" (Thornton 2017, p. 59). Traditional African societies have been described as societies in which everybody belongs to the ritual system of the entire society and within that broad and open community individual people take their issues to whoever they think can help them (Ruel 1997, p. 199). Beyond Christianity in Egypt and Ethiopia, and Islam in north and east Africa, there were no congregations or equivalents to congregations in Africa before the colonial era, and that is an important reason why missionaries and others from Europe did not recognize African religion for so long, as mentioned at the outset of this article. Thornton continues, "sangomas are not priests as they do not lead a congregation. They provide individuated services to clients, drawing on a broadly construed cultural tradition" (Thornton 2017, p. 59). The focus in the Ngoma healing tradition is not on the community, but on the religious specialist and his vertical relationship to individuals who are looking for the spiritual way to deal with their problems that works for them.

In the 1960s the Ghanaian scholar C.G. Baëta investigated the new African Initiated Churches that were formed around prophets (Baëta 1962). Baëta speculates, "[Prophetism] appears to me to be a perennial phenomenon of African life" (Baëta 1962, p. 6). The figure of the prophet as an "individual endowed with a striking personality and the ability to impose his own will on others, believing himself, and believed by others to be a special agent of some supernatural being or force, will emerge from time to time and secure a following" (Baëta 1962, pp. 6-7). People in Africa are said to look for religious services from their pastor or prophet. As a parent the man (or woman) of God offers to take care of them; the language of parentage is often very important: the pastor is considered to be one's 'spiritual father' or 'papa' (Haynes 2017b, p. 107). Baëta continues, "Powers traditionally credited to such people, of healing, revealing hidden things, predicting the future, cursing and blessing effectually, etc., will be attributed to him whether he claims them or not" (Baëta 1962, p. 7). The traditional healer or healing prophet of African Traditional Religions has been seamlessly transformed into the Christian prophet of African Initiated Churches, scholars have noted, and nowadays we find the same figure as the prophet leading the many Neo-Pentecostal ministries (Sundkler 1948; Banda 2016). Paul Gifford describes how in Pentecostalized Christianity the personal status of the pastor is enhanced compared to ministers in traditional mainline churches, "These great 'men of God' and their personal gifts or 'anointing' achieve all that is required" (Gifford 2004b, p. 108). People generally do not visit these churches and ministries in order to belong to a particular community, but they, first of all, want to visit the powerful prophet, "It is obvious that people flock to them for their gifts, not to form communities with other believers; of the crowds who flock to a prophetic ministry most will not know others there-the links are all vertically towards the prophet, rather than horizontally between believers" (Gifford 2004b, p. 108). The focus is on the vertical relationship with the man or woman of God and not on the horizontal relationships within the community. 
This vertical relationship is reflected in the second liturgical practice that has spread from Neo-Pentecostal ministries to almost all churches and ministries in Africa nowadays, as well, namely the altar call. During the altar call the pastor invites people who need extra prayers to come forward and there he or she will pray for them. Often the prayer does not involve much more than a shouting of "In Jesus' name!" while touching someone's forehead. Since often many people come forward during an altar call, in some churches the pastor has helpers who pray for people as well. Most people, however, will try to be prayed over by the powerful man of God himself with his special anointing, to receive their way to dealing with their problems from the big man of God himself.

The vertical hierarchical tie to the prophet or pastor is the dominant form of social organization within contemporary Pentecostalized Christianity. Obviously, the contrast between traditional mission churches and Pentecostalized Christianity is not absolute: in both types of churches Christians gather to look both for fulfilment of their personal individual religious needs and for a sense of belonging to a community. Yet, in Pentecostalized Christianity the focus is most often not on this group identity, as can be seen in the names of many of the new Neo-Pentecostal ministries: they designate themselves as 'international'. As political theorist Ruth Marshall notes for Nigerian Pentecostals, they "are part of a transnational community without a 'proper place,' that in many ways goes beyond the 'proper' or the 'authentic' altogether, and the closure they imply. Being Pentecostal does not furnish a distinct identity, nor does it imply a necessary institutional identification" (Marshall 2010, p. 209). As anthropologist Birgit Meyer observes concerning Pentecostal-Charismatic churches (PCCs), "What is distinctly new about PCCs is their propagation of the Prosperity Gospel and their strong global inclination" (Meyer 2004, p. 453). It is characteristic of the Neo-Pentecostal movement in Africa that they do not strive to create local communities. Lateral relationships, interdependence and mutuality among believers who frequent a particular prophet are important, but by far not as important as the spiritual power of the man of God and one's vertical relationship with him. Pentecostal leaders in Africa often criticize the traditional patron-client systems that are common in society, yet, on the other hand, in practice on a large scale they set up their own patron-client networks and hierarchical social structures for their own financial benefit (Burgess 2008, p. 45; Smith 2001, pp. 589-90). Within the buildings of churches and ministries one may find large groups of people, but, in many ways, these people cannot be said to form a community. It is characteristic of these kind of gatherings that when three people died during a stampede in a Neo-Pentecostal ministry in Pretoria in 2018 it took several weeks before these people were identified. People do not know each other. Everyone is there merely to visit the anointed man or woman of God. Within the already assumed open-ended organic community, people do not so much look for a community to join or belong to, but they look for who can help them with the problems that are bothering them.

In the context of African Traditional Religions religious specialists are generally called 'traditional healers.' Many scholars have noted that healing and religion are intricately connected in the African way of life (for a list of sources see (Van den Bosch-Heij 2013, p. 27)). The church is generally considered to be a place of healing and it is often one of the most common motivations for people to frequent a particular church or ministry -in particular African Initiated Churches-that they have found healing there (Öhlmann et al. 2016, p. 2). It is important to keep in mind here that healing has a broader more holistic meaning in Africa than it has a modern Western context. As Bernhard Udelhoven comments, "Few people would come to a modern hospital to be treated against bad luck, the inability to find a husband, to find a lost or stolen item or to have the name of the thief who stole it revealed. Traditional healers, in contrast, easily group such categories together with physical healing" (Udelhoven 2017, p. 123). This traditional concept of healing reflects the kind of healing that most people expect from churches and ministries in the contemporary Pentecostalized context as well. People generally frequent a particular church or ministry because they think that the man or woman of God present there can help them to deal with whatever problem in life they are struggling with. Churches and ministries can be seen as a kind of holistic hospitals. 
Like mass prayer and altar calls, the close connection between religion and healing shows how African religion can be properly characterized as religion with a community that is not a community. In a regular modern hospital one will find many people together in one building, but they have nothing in common except for their desire to see a doctor. Medical doctors provide services to the community in general and in their hospitals one will find a gathering of people, but these people do not form a community. A government, for example, would hardly ever ask doctors to speak on behalf of the haphazard group of people in their hospitals. Pastors and prophets in the contemporary context of Pentecostalized Christianity in Africa have become like these doctors with hospitals: they deliver services to whoever desires them, but they do not focus on building communities, nor could they speak on behalf of a particular community. In this context the only community that matters is the community of society as a whole. Within this open-ended organic community, however, individuals may need protection against greedy religious service providers. In many countries in Africa, like Kenya, Zambia, Botswana and South Africa, the government currently tries to regulate religion. In doing so they treat pastors, prophets and other religious leaders not as community leaders representing a particular segment of society, but they treat them as service deliverers in a market situation whose accountability, staffing, equipment and so on need to be in order (Kroesbergen forthcoming).

One may find many people gathered in a church or hall used by Neo-Pentecostal ministries, but, in many ways, these people do not form a community. Ad hoc people may form a group or small community, but that is often accidental. In churches and ministries many people come together and engage in mass prayer, for example, but generally one does not find a community there in the same way as there is no community among the patients in a hospital. In important respects, religion in Africa is becoming religion without beliefs again, and religion in Africa does not really have communities either.

\section{Conclusions}

My analysis of self-help style sermons, church hopping and mass prayer shows that the Pentecostalization of contemporary Christianity in Africa in many ways brings back a traditional African concept of religion. The focus of sermons and literature in Neo-Pentecostal circles is most often on how the prophet can help an individual to deal with his or her problems, irrespective of what picture of the world this prophet may or may not adhere to. People often look around to find who can help them, without considering dogmatic positions or caring about what it means for their world picture to go to this or that powerful man or woman of God. The proper category to which the African concept of religion belongs is that of the negative pseudo-species of responses to what is not explainable and not knowable and not secure. The importance of 'mass prayer' and 'altar calls' shows that Neo-Pentecostal ministries are not really communities, but organized around the vertical relationship between the prophet as a religious service provider and his or her individual client. Without beliefs in a way there is no community of believers either. Religion in Africa is in many respects becoming religion without belief and community again.

Funding: This research was funded by UP Senior Postdoctoral Fellowship Programme, University of Pretoria.

Conflicts of Interest: The author declares no conflict of interest.

\section{References}

Asamoah-Gyadu, J. Kwabena. 2010. Pentecostalism in Africa. In African Theology on the Way: Current Conversations. Edited by Diane B. Stinton. London: SPCK, pp. 56-67.

Asamoah-Gyadu, J. Kwabena. 2012. "From Prophetism to Pentecostalism": Religious Innovation in Africa and African Religious Scholarship. In African Traditions in the Study of Religions in Africa: Emerging Trends, Indigenous Spirituality and the Interface with Other World Religions. Edited by Afe Adogame, Ezra Chitando and Bolaji Bateye. Aldershot: Ashgate, pp. 161-74.

Asamoah-Gyadu, J. Kwabena. 2013. Contemporary Pentecostal Christianity: Interpretations from an African Context. Eugene: Wipf \& Stock. 
Asamoah-Gyadu, J. Kwabena. 2016. Faith, An Alien and Narrow Path of Christian Ethics in Migration. In Religion, Migration and Identity: Methodological and Theological Explorations. Edited by Marta Frederiks. Leiden: Brill, pp. 152-70.

Ashforth, Adam. 1998. Reflections on Spiritual Insecurity in a Modern African City (Soweto). African Studies Review 41: 39-67. [CrossRef]

Ashforth, Adam. 2000. Madumo: A Man Bewitched. Chicago: University of Chicago Press.

Ashforth, Adam. 2011. AIDS, religious enthusiasm and spiritual insecurity in Africa. Global Public Health 6: $132-47$. [CrossRef]

Baëta, Christian Gonçalves. 1962. Prophetism in Ghana: A Study of Some 'Spiritual Churches'. London: SCM Press.

Banda, Lameck. 2016. Prophets of God or neo-diviners? A theological assessment of prophecy in Zambia today. In Prophecy Today: Reflections from a Southern African Context. Edited by Hermen Kroesbergen. Wellington: CLF, pp. 208-24.

Blum, Jason N. 2018. Belief: Problems and Pseudo-Problems. Journal of the American Academy of Religion 86: 642-64. [CrossRef]

Bubandt, Nils. 2014. The Empty Seashell: Witchcraft and Doubt on an Indonesian Island. Ithaca: Cornell University Press.

Burgess, Richard H. 2008. Freedom from the Past and Faith for the Future: Nigerian Pentecostal Theology in Global Perspective. Penteco Studies 7: 29-63.

Cheyeka, Austin. 2015. Conversion to Pentecostalism in Zambia. In Religious Conversion: An African Perspective. Edited by Brendan Carmody. Lusaka: Gadsden, pp. 231-48.

Chidester, David. 1996. Savage Systems: Colonialism and Comparative Religion in Southern Africa. Charlottesville: University Press of Virginia.

Clarke, Clifton R. 2011. African Christology: Jesus in Post-Missionary African Christianity. Eugene: Wipf \& Stock.

Clarke, Clifton R. 2014. Call and response: Toward an African Pentecostal theological method. In Pentecostal Theology in Africa. Edited by Clifton R. Clarke. Eugene: Pickwick, pp. 21-39.

Copeland, Kenneth. 1974. The Laws of Prosperity. Fort Worth: Kenneth Copeland Publications.

Copeland, Gloria. 1978. God's Will is Prosperity: A Roadmap to Spiritual, Emotional, E Financial Wholeness. Fort Worth: Kenneth Copeland Publications.

Corten, Andre, and Ruth Marshall-Fratini, eds. 2001. Between Babel and Pentecost: Trans-National Pentecostalism in Africa and Latin America. Bloomington: Indiana University Press.

de Kok, Bregje. 2004. Christianity and African Traditional Religion: Two Realities of a Different Kind: A Cultural Psychological Study of the Way Christian Malawians Account for Their Involvement in African Traditional Religion. Zomba: Kachere.

Ellis, Stephen, and Gerrie Ter Haar. 1998. Religion and politics in Sub-Saharan Africa. The Journal of Modern African Studies 36: 175-201. [CrossRef]

Evans-Pritchard, Edward E. 1937. Witchcraft, Oracles and Magic among the Azande. Oxford: Clarendon.

Faulkner, Mark. 2016. Religion in Africa. In Religions in the Modern World: Traditions and Transformations, 3rd ed. Edited by Linda Woodhead, Christopher Patridge and Hiroko Kawanami. Abingdon: Routledge.

Frahm-Arp, Maria. 2014. African Pentecostalism and Gender Roles. In Pentecostal Theology in Africa. Edited by Clifton R. Clarke. Eugene: Pickwick, pp. 150-61.

Geschiere, Peter. 2016. Witchcraft, Shamanism, and Nostalgia; A Review Essay. Comparative Studies in Society and History 58: 242-65. [CrossRef]

Gifford, Paul. 2004a. Persistence and change in contemporary African religion. Social Compass 51: 169-76. [CrossRef]

Gifford, Paul. 2004b. Ghana's New Christianity: Pentecostalism in a Globalizing African Economy. London: Hurst \& Company.

Gifford, Paul. 2008. The Bible in Africa: A novel usage in Africa's new churches. Bulletin of the School of Oriental and African Studies, University of London 71: 203-19. [CrossRef]

Gordon, David M. 2012. Invisible Agents, Spirits in a Central African History. Athens: University Press.

Hackett, Rosalind I. J. 1988. Religion in Calabar: The Religious Life and History of a Nigerian Town. Berlin: W. de Gruyter.

Haynes, Naomi. 2017a. Learning to pray the Pentecostal way: Language and personhood on the Zambian Copperbelt. Religion 47: 35-50. [CrossRef] 
Haynes, Naomi. 2017b. Moving by the Spirit; Pentecostal Social Life on the Zambian Copperbelt. Oakland: University of California Press.

Horton, Robert. 1993. Patterns of thought in Africa and the West: Essays on Magic, Religion and Science. Cambridge: Cambridge University Press.

Kalu, Ogbu. 2003. Pentecostal and Charismatic Reshaping of the African Religious Landscape in the 1990s. Mission Studies 20: 84-111. [CrossRef]

Kalu, Ogbu. 2008. African Pentecostalism: An Introduction. Oxford: Oxford University Press.

Kroesbergen, Hermen. 2017. Another way of looking at the prosperity gospel: A hermeneutics of seeking first the Kingdom. In Neo-Pentecostalism in Southern Africa-Some Critical Reflections. Edited by Hermen Kroesbergen. Wellington: CLF, pp. 111-32.

Kroesbergen, Hermen. forthcoming. The Language of Faith in Southern Africa: Spirit World, Power, Community, Holism. Cape Town: AOSIS Scholarly Books.

Landau, Paul. 1999. "Religion" and Christian Conversion in African History: A New Model. The Journal of Religious History 23: 8-30. [CrossRef]

Lofton, Kathryn. 2012. Introduction to the Yale Roundtable on Belief. Method and Theory in the Study of Religion 24: 51-54. [CrossRef]

Lopez, Donald. 1998. Belief. In Critical Terms for Religious Studies. Edited by Mark Taylor. Chicago: Chicago University Press, pp. 21-35.

Marshall, Ruth. 2009. Political Spiritualities: The Pentecostal Revolution in Nigeria. Chicago: University of Chicago Press.

Marshall, Ruth. 2010. The sovereignty of miracles; Pentecostal political theology in Nigeria. Constellations 17: 197-223. [CrossRef]

McCauley, James F. 2012. Africa's new big man rule? Pentecostalism and patronage in Ghana. African Affairs 112: 1-21. [CrossRef]

Meyer, Birgit. 1999. Translating the Devil: Religion and Modernity Among the Ewe in Ghana. Edinburgh: Edinburgh University Press.

Meyer, Birgit. 2004. Christianity in Africa; From African independent to Pentecostal-charismatic churches. Annual Review of Anthropology 33: 447-74. [CrossRef]

Meyer, Birgit. 2007. Pentecostalism and Neo-Liberal Capitalism: Faith Prosperity and Vision in African Pentecostal-Charismatic Churches. Journal for the Study of Religion 20: 5-26. [CrossRef]

Newell, Stephanie. 2008. Corresponding with the city: Self-help literature in urban West Africa. Journal of Postcolonial Writing 44: 15-27. [CrossRef]

Öhlmann, Phillip, Marie-Luise Frost, and Wilhelm Gräb. 2016. African Initiated Churches' potential as development actors. HTS Teologiese Studies/Theological Studies 72: 1-12. [CrossRef]

Onyinah, Opoku. 2007. African Christianity in the twenty-first century. Word \& World 27: 305-14.

Oyedepo, David O. 2005. Understanding Financial Prosperity. Lagos: Dominion.

Oyedepo, David O. 2011. Covenant Wealth. Lagos: Dominion. First published 1992.

Platvoet, Jan, and Henk van Rinsum. 2003. Is Africa incurably religious? Exchange 32: 123-53. [CrossRef]

Pouillon, Jean. 2016. The verb 'to believe'; Reprint, translated by John Leavitt. HAU: Journal of Ethnographic Theory 6: 485-92. [CrossRef]

Prince, Derek. 1986. God's Plan for Your Money. New Kensington: Whitaker House.

Prince, Derek. 2011. The Promise of Provision. Minneapolis: Chosen Books.

Pype, Katryn. 2015. The liveliness of Pentecostal/charismatic popular culture in Africa. In Pentecostalism in Africa: Presence and Impact of Pneumatic Christianity in Postcolonial Societies. Edited by Martin Lindhardt. Leiden: Brill, pp. 345-78.

Rhees, Rush. 1969. Without Answers. London: Routledge \& Kegan Paul.

Ruel, Malcolm. 1997. Belief, Ritual and the Securing of Life: Reflective Essays on a Bantu Religion. Leiden: Brill.

Sanders, Todd. 2016. The Pendulum Swings. HAU: Journal of Ethnographic Theory 6: 493-98. [CrossRef]

Schilbrack, Kevin. 2010. Religions: Are There Any? Journal of the American Academy of Religion 78: 1112-38. [CrossRef]

Smith, Wilfred Cantwell. 1962. The Meaning and End of Religion. Minneapolis: Fortress.

Smith, Daniel Jordan. 2001. 'The Arrow of God': Pentecostalism, Inequality, and the Supernatural in South-Eastern Nigeria. Africa 71: 587-613. [CrossRef] 
Soko, Lukas. 2010. A Practical Theological Assessment of the Schisms in the Reformed Church in Zambia (1996-2001). Ph.D. dissertation, Stellenbosch University, Stellenbosch, South Africa.

Sundkler, Bengt. 1948. Bantu Prophets in South Africa. London: Lutterworth.

Thornton, Robert J. 2017. Healing the Exposed Being: A South African Ngoma Tradition. Johannesburg: Wits University Press.

Udelhoven, Bernhard. 2017. Seeing Witchcraft. Journal of Global Catholicism 2: 120-42. [CrossRef]

van de Kamp, Linda. 2010. Burying life: Pentecostal religion and development in urban Mozambique. In Development and Politics from Below: Exploring Religious Spaces in the African State. Edited by B. Bompani and Maria Frahm-Arp. London: Palgrave Macmillan, pp. 152-71.

Van den Bosch-Heij, Deborah. 2013. Spirit and Healing in Africa: A Reformed Pneumatological Perspective. Bloemfontein: SUN Media.

Walls, Andrew F. 1996. African Christianity in the history of religions. Studies in world Christianity 2: 183-203. [CrossRef]

Wariboko, Nimi. 2014. Nigerian Pentecostalism. Rochester: University of Rochester Press.

Winch, Peter. 1972. Ethics and Action. London: Routledge \& Kegan Paul.

Wittgenstein, Ludwig. 1993. Philosophical Occasions: 1912-1951. Indianapolis: Hackett.

Wittgenstein, Ludwig. 1997. On Language and Ritual. In Rush Rhees on Philosophy and Religion. Edited by Dewi Zephaniah Phillips. Cambridge: Cambridge University Press, pp. 65-96.

Zizek, Slavoj. 2014. Event: Philosophy in Transit. London: Penguin.

(C) 2019 by the author. Licensee MDPI, Basel, Switzerland. This article is an open access article distributed under the terms and conditions of the Creative Commons Attribution (CC BY) license (http://creativecommons.org/licenses/by/4.0/). 